\title{
A Study of Surgical Cases During Earthquake Disaster in A Medical College
}

\author{
Kanchan K.C, ${ }^{1}$ Raj Kumar Thapa, ${ }^{2}$ Sanubhai Khadka, ${ }^{1}$ Damodar Paudel ${ }^{3}$ \\ 'Department of General Practice and Emergency Medicine, Kathmandu Medical College Teaching Hospital, Sinamangal, \\ Kathmandu, Nepal, '2Department of Medicine, Shree Birendra Hospital, Chhauni, Kathmandu, Nepal, ${ }^{3}$ Department of \\ Medicine, Nepal Police Hospital, Kathmandu, Nepal.
}

\section{ABSTRACT}

Introduction: An earthquake is an intense shaking of earth's surface which is caused by movements in earth's outermost layer. The earthquake of $25^{\text {th }}$ April 2015, with a magnitude of 7.8 richter scale with its major aftershock on $12^{\text {th }}$ May 2015 of 7.3 richter scale claimed around 8,962 lives across several districts of Nepal with 22,302 injuries. In this study we tried to figure out various surgical cases and the surgical procedures performed in a tertiary care hospital during an earthquake disaster.

Methods: This study was a descriptive cross-sectional study of hospital data on all admitted surgical cases during an earthquake disaster. A total of 238 earthquake victims brought to emergency department of Kathmandu Medical College Teaching Hospital , a tertiary care center, from 26th April 2015 to $7^{\text {th }}$ Jun 2015, for the period of 42 days were included. Those brought dead and discharged after primary treatments were excluded. Data obtained were entered and analysed in Microsoft Excel 2010.

Results: Among 238 patients enrolled, 122 (51\%) were male and 116 (49\%) female with male to female ratio of 1.05:1. Age group (31-60 years) with an average age of 45 years were encountered most frequently $110(46 \%)$ with the maximum number of patient burden from Sindhupalchowk district $80(33.6 \%)$. Orthopedic surgery $185(76 \%)$ appeared to be the most frequent followed by neurosurgery, plastic surgery, general surgery and dental surgery.

Conclusions: In natural disaster like earthquakes, traumatic injuries are very common and thereby various surgical procedures especially ortho-plastic are the domain of treatment modalities. Disaster preparedness and combined surgical team effort needs to be focused to reduce both mortality and morbidity.

Keywords: disaster; earthquake; Nepal; surgery.

\section{INTRODUCTION}

Nepal is the $11^{\text {th }}$ most earthquake prone country in the world in terms of seismic vulnerability. In the history of Nepal, the earthquake of $25^{\text {th }}$ April 2015, with a magnitude of 7.8 richter scale and its major aftershock on $12^{\text {th }}$ May 2015 , with 7.3 richter scale are the most devastating. It claimed 8,962 lives across several districts with 22,302 injuries. $^{1-4}$

Reports from 2006 to 2016 that described 10 earthquakes worldwide found that between 600 and 220,000 people were killed per event. ${ }^{5}$ The impact of earthquakes has been reported to the highest in Asia, with China and Pakistan accounting for $40 \%$ of all earthquake related mortality. ${ }^{6}$ Trauma is the most

Correspondence: Dr. Kanchan K.C, Department of General Practice and Emergency Medicine, Kathmandu Medical College Teaching Hospital, Sinamangal, Kathmandu, Nepal. Email: kanchanthapakc@ gmail.com, Phone: $+977-9841602407$. 
K.C et al. A Study of Surgical Cases During Earthquake Disaster in A Medical College

common cause of mortality and morbidity through earthquake. ${ }^{7}$ Major surgery defined as an operation involving a considerable hazard or risking of life whereas minor surgery is a simple operation not considered to involve a risk to life. ${ }^{8}$

The aim of this study is to estimate various surgical cases and the surgical procedures performed during an earthquake disaster.

\section{METHODS}

A descriptive cross-sectional study was done utilizing hospital data on all admitted surgical cases during an earthquake disaster. Earthquake victims of all age groups, a total of 238 patients brought to emergency of Kathmandu Medical College Teaching Hospital (KMCTH), a tertiary care hospital, from $26^{\text {th }}$ April 2015 to $7^{\text {th }}$ Jun 2015, for a period of 42 days were enrolled. Those patients who underwent various surgical procedures after admission in respective surgical departments were included and those brought dead and discharged after primary treatments were excluded.

Data from register book were retrieved after ethical approval from Institutional Review Committee of KMCTH. Standardized questionnaire developed by the researcher was used to obtain clinical and sociodemographic characteristics of the patients after getting informed consent. Depending upon the surgical procedure performed, cases were categorized into either major or minor surgery. Data obtained were entered and analysed in Microsoft Excel 2010. The descriptive statistical analysis was done.

\section{RESULTS}

Among 238 patients enrolled, 122 (51\%) were male and $116(49 \%)$ female with male to female ratio of 1.05:1. Age group (31-60 years) with an average age of 45 years were encountered most frequently 110 $(46 \%)$ with the maximum number of patient burden from Sindhupalchowk 80 (33.6\%) and Kathmandu 40 $(16.8 \%)$ districts (Table 1$)$.

\begin{tabular}{|ll|}
\hline Table 1. Distribution of patients in districts. \\
\hline Districts & $\mathbf{n}(\%)$ \\
Kathmandu & $40(16.81)$ \\
Lalitpur & $8(3.36)$ \\
Bhaktapur & $32(13.45)$ \\
Sindhupalchowk & $80(33.61)$ \\
Rasuwa & $10(4.20)$ \\
Gorkha & $11(4.62)$ \\
Dhading & $9(3.78)$
\end{tabular}

\begin{tabular}{ll|} 
Nuwakot & $8(3.36)$ \\
Kavrepalanchowk & $16(6.72)$ \\
Ramechhap & $10(4.20)$ \\
Dolakha & $8(3.36)$ \\
Lamjung & $1(0.42)$ \\
Solukhumbu & $1(0.42)$ \\
Sankhuwasabha & $1(0.42)$ \\
Bardiya & $1(0.42)$ \\
Saptari & $1(0.42)$ \\
Sarlahi & $1(0.42)$ \\
Total & $238(100)$ \\
\hline
\end{tabular}

In overall surgical procedures, orthopedic surgery appeared to be the most frequent followed by neurosurgery, plastic surgery, general surgery and dental surgery respectively (Figure 1)

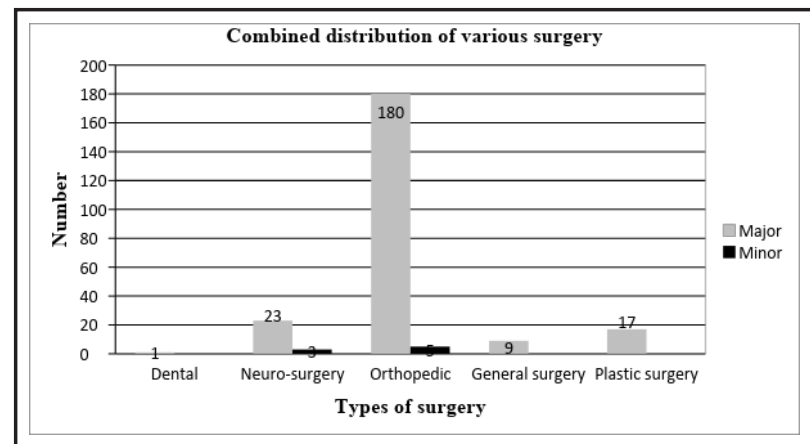

Figure 1. Combined distribution of various surgery

Out of various orthopedic surgery performed, open reduction and internal fixation (ORIF) was the most frequent major surgery $111(61 \%)$ with the total burden of 185 (76\%) (Table 2).

\begin{tabular}{|ll|}
\hline \multicolumn{2}{l}{ Table 2. Distribution of major orthopedic surgery. } \\
\hline Major operation & $\mathrm{n}(\%)$ \\
Amputation & $3(1.7)$ \\
External fixation & $10(5.6)$ \\
Internal fixation & $111(61.7)$ \\
LCDCP $^{*}$ & $10(5.6)$ \\
DHS $^{\dagger}$ & $2(1.1)$ \\
Arthrotomy & $2(1.1)$ \\
Traction & $2(1.1)$ \\
Debridement & $25(13.88)$ \\
CR $^{\ddagger}$ & $3(1.6)$ \\
K-wire fixation & $3(1.6)$ \\
TENS & $2(1.1)$ \\
Secondary closure & $2(1.1)$
\end{tabular}


K.C et al. A Study of Surgical Cases During Earthquake Disaster in A Medical College

\begin{tabular}{|ll|} 
Spinal decompression & $1(0.55)$ \\
TBW ${ }^{\prime \prime}$ & $2(1.1)$ \\
Relocation & $2(1.1)$ \\
Total & $180(100)$ \\
\hline
\end{tabular}

*Limited contact dynamic compression plate. ${ }^{\dagger}$ Dynamic hip screw.

${ }^{\ddagger}$ Closed reduction.

${ }^{\S}$ Transcutaneous electrical nerve stimulation.

I Tension band wiring.

Likewise, decompressive craniectomy was the most frequent major neurosurgical procedure 9 (39\%) (Figure 2) and debridement with split skin graft (SSG) 13 (76\%) in plastic surgery. In general surgery, laparotomy and debridement accounted for $2(22 \%)$ each (Figure 3$)$.

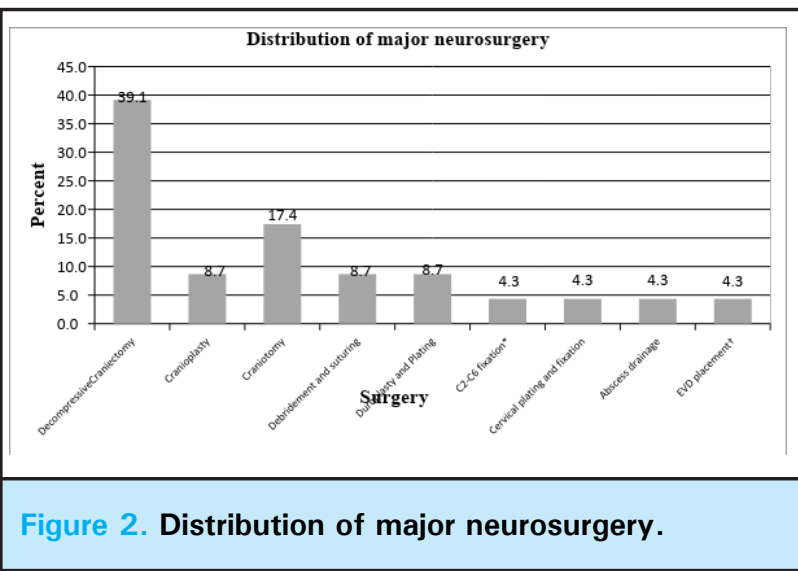

*Cervical vertebra $2^{\text {nd }}$ to $6^{\text {th }}$ fixation.

${ }^{\dagger}$ External ventricular drain placement.

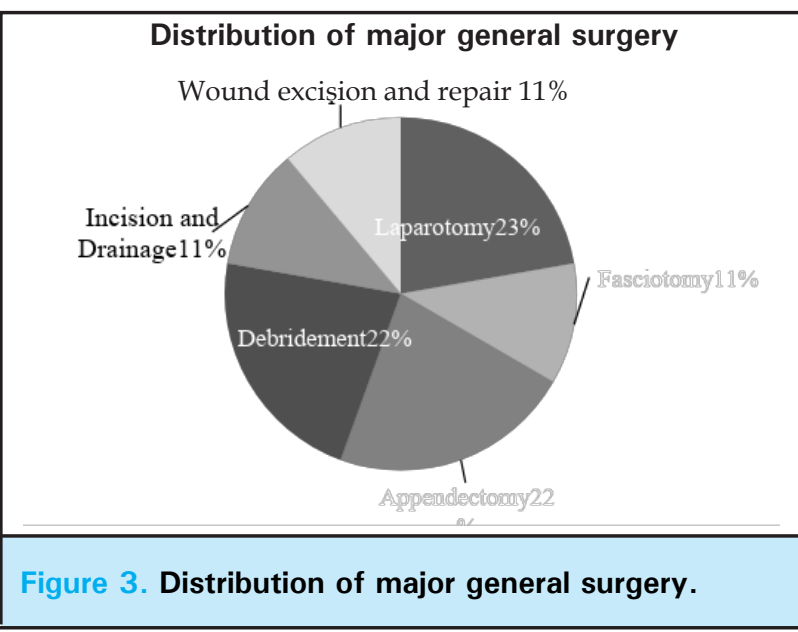

\section{DISCUSSION}

In our study population, almost equal number of male $122(51 \%)$ and female $116(49 \%)$ were encountered with the most frequent age group of 31-60 years. In a similar study by Thapa SS et al, ${ }^{9}$ majority of population $(61 \%)$ were in the age group 16-60 years. Likewise, in the prospective hospital based study by Giri S et al, ${ }^{10}$ around $74 \%$ population were of the age group 15-65 years and in the earthquake disaster relief mission in Nepal by Singapore Armed Forces, ${ }^{11}$ there were $77.9 \%$ adults.

Out of 35 seriously earthquake stricken districts maximum number of patient burden in our hospital were from Sindhupalchowk district 80 (33.6\%) followed by Kathmandu 40 (16.8\%) and then Bhaktapur 32 $(13.4 \%)$. In the similar Dhulikhel hospital based study by Giri $S$ et al, ${ }^{10}$ bulk of the patients were also from Sindhupalchowk district $55 \%$, possibly because of nearby location of the hospital.

In epidemiology of traumatic injuries from earthquake by Ramirez $\mathrm{M}$ et $\mathrm{al}^{12}$ it is stated that according to human/individual factors, built environment and the seismic/geologic factors the number and type of injuries caused by earthquake vary. However, most of the time earthquake related injuries are orthopedic in nature, commonly fractures that of the long bones. ${ }^{13}$ In our study also, out of various surgical cases, majority were related to orthopedics $77.7 \%$ and remaining $22.3 \%$ were non-orthopedics in nature (neurosurgery $10.9 \%$, plastic surgery $7.1 \%$, general surgery $3.7 \%$ and dental surgery $0.04 \%$.

Similar results were also seen in the study by Thapa SS et $\mathrm{al}^{9}{ }^{9}$ where $81 \%$ were orthopedics and $19 \%$ nonorthopedics, commonly involving lower limb fractures, around $77 \%$. Likewise, in a review earthquake related article by MacKenzie JS et al, ${ }^{13}$ suggested $87 \%$ cases that of orthopedics, nearly $65 \%$ of them were fractures commonly involving the lower limbs. It was also supported by related article by Shrestha JM et al, ${ }^{14}$ on role of plastic reconstructive surgery during Nepal earthquake 2015.

In orthopedic surgery, open reduction and internal fixation (ORIF) $111(61.7 \%)$ was the commonest surgery performed followed by debridement 25 $(13.9 \%)$. In contrary, external fixation and debridement constituted the bulk of the cases in a similar study by Thapa SS et al, ${ }^{9}$ possibly because of the type of fracture cases received in their center. In earthquake related disaster situations, external fixation is vital for proper management of fractures and soft tissue stabilization and the ratio of external fixation to ORIF mainly rely on the time of arrival of disaster response team at the earthquake site, supported by Mclntyre $\mathrm{T}$ et $\mathrm{al}^{15}$ on Haiti earthquake and Rajpura $\mathrm{A}$ et $\mathrm{al}{ }^{16}$ on Pakistan earthquake. However, in a review article by MacKenzie et $\mathrm{al}^{,{ }^{13}}$ on average $12 \%$ of fractures were stabilized by 
external fixation and the use of external fixation vary from less than $2 \%$ to more than $30 \%$.

In Neurosurgery, decompressive craniectomy 9 (39.1\%) was the commonest surgery performed in our study. Here it appears to be the second most common surgery after orthopedics in post earthquake scenario. In a similar study of 1999 Taiwan earthquake, ${ }^{17}$ around $30 \%$ of people died from head injuries and after lower limb injuries head injuries were the second most frequent in 2008 Sichuan earthquake. ${ }^{18}$

Among all plastic surgical cases in our study, debridement with split skin grafting (SSG) accounted $13(76.5 \%)$. Similarly in a study by Shrestha JM et al, ${ }^{14}$ $22 \%$ of the total operations were for soft tissue injury and the most common surgery was SSG 39 (34\%). Skin grafting after soft tissue injury was a common procedure ranging from $22 \%$ to $43 \%$, Rajpura $A$ et al, ${ }^{16}$ and Clover AJ et al. ${ }^{19}$ Similar findings in studies by Zhang $\mathrm{J}$ et al, ${ }^{20}$ and Wolf $\mathrm{Y}$ et al. ${ }^{21}$

For non-salvageable limbs, amputation rate in our study was $3(1.7 \%)$. It was supported by various studies where amputation rates ranges between 0.4 to $11 \%$, Phalkey $\mathrm{R}$ et $\mathrm{al}{ }^{22}$ and $\mathrm{Yang} \mathrm{C}$ et al. ${ }^{23}$

In General surgery, laparotomy and debridement accounted for 2 (22.2\%) each in our study. In one series from Haiti earthquake, gastrointestinal cases were only $2 \%$ of the total operative volume and bulk occupied by plastic surgery and orthopedics. ${ }^{24}$ In contrast, in the study of patterns of abdominal injury in thousands of earthquake victims of Wenchuan earthquake, abdominal injury was often accompanied with multiple injuries and around $32 \%$ had earthquake-related abdominal injury where spleen was the most commonly injured abdominal organ (18\%), showing various factors define injury patterns. ${ }^{25}$

In our study only one documented mortality 1 (0.4\%) in total admitted surgical cases. In an earthquake, the number of injured far exceeds the death toll and on average injury to mortality ratio stands at around $3: 1 .^{26,27}$ In the study done by Thapa SS et al ratio was 2.5:1 and overall mortality of earthquake related injured hospitalized patients was $2.6 \% .^{9}$ In a similar study by Giri $\mathrm{S}$ et al the 90 days mortality was only $2 \% .{ }^{10}$ However overall mortality among such can be as high as $8 \% .{ }^{28}$ The limitations of our study being the data of a single referral center and no follow up visits study.

\section{CONCLUSIONS}

In various earthquake related articles including ours, it is seen that ortho-plastic and allied surgical backup in hospitals should be focused to reduce both mortality and morbidity. Besides disaster preparedness, national policy, a systematic approach and a team effort is a must to be effective in such disastrous situations.

\section{ACKNOWLEDGEMENTS}

We express our sincere gratitude to statistician Mr. Nirmal Bajracharya, Mr. Hari Khadka and Dr. Krishna Rana for their continuous support and valuable expert contribution in completing this research.

\section{Conflict of interest: None.}

\section{REFERENCES}

1. National seismological center. Aftershocks of Gorkha earthquake: National seismological center, department of mines and geology, Ministry of industry. 2017. [Full Text]

2. Nepal disaster risk reduction portal. Earthquake: Nepal disaster risk reduction portal, Ministry of home affairs. 2016. [Full Text]

3. Government Nepal. Nepal earthquake 2015: Post disaster recovery framework 2016-2020. National reconstruction authority, Government of Nepal. 2016. [Full Text]

4. WHO. Humanitarian crisis after the Nepal earthquakes 2015. Nepal. 2015;(34). [Full Text]

5. EM-DAT. The international disaster database. Belgium: Centre for research on the epidemiology of disasters. 2017;(34). [Full Text]
6. Doocy S, Daniels A, Packer C, Dick A, Kirsch TD. The human impact of earthquakes: a historical review of events 1980-2009 and systematic literature review. PLOS Currents. 2013;5. [PubMed]

7. Liang NJ, Shih YT, Shih FY, Wu HM, Wang HJ, Shi SF et al Disaster epidemiology and medical response in the Chi-Chi earthquake in Taiwan. Ann Emerg Med. 2001;38(5):549-55. [PubMed]

8. Thomas CL. Taber's Cyclopedic Medical Dictionary. $18^{\text {th }}$ ed. Philadelphia: FA Davis Company; 1997(2): p1870. [Full Text]

9. Thapa SS, Lamichhane A, Mahara DP. Injury epidemiology after 7.8 richter Gorkha earthquake in Nepal: A retrospective study of injuries treated at Tribhuvan university teaching hospital. Journal of Institute of Medicine. 2018 Aug;40(2):33-37. [Full Text] 
10. Giri S, Risnes K, Uleberg O, Rogne T, Shrestha SK, Nygaard $\varnothing \mathrm{P}$, et al. Impact of 2015 earthquakes on a local hospital in Nepal: A prospective hospital-based study. PLoS one. 2018 Feb 2;13(2). [PubMed]

11. Ho ML, Lim JZ, Tan MZ, Kok WL, Zhang JR, Tan MY, et al. Humanitarian assistance and disaster relief mission by a tripartite medical team led by the Singapore armed forces after the 2015 Nepal earthquake. Singapore Med Journal. 2016;57:426-31. [PubMed]

12. Ramirez M, Peek-Asa C. Epidemiology of traumatic injuries from earthquakes. Epidemiol Rev. 2005;27:47-55. [PubMed]

13. MacKenzie JS, Banskota B, Sirisreetreerux N, Shafiq B, Hasenboehler EA. A review of the epidemiology and treatment of orthopaedic injuries after earthquakes in developing countries. World journal of emergency surgery. 2017 Dec;12(1):9. [PubMed]

14. Shrestha JM, Rayamajhi S, Lohani I. Role of plastic reconstructive surgery in the management of earthquake victims of Nepal in Tribhuvan university teaching hospital. Journal of Institute of Medicine. 2016 Aug-Dec;38:2-3. [Full Text]

15. McIntyre T, Hughes CD, Pauyo T, Sullivan SR, Rogers SO $\mathrm{Jr}$, Raymonville $\mathrm{M}$ et al. Emergency surgical care delivery in post-earthquake Haiti: Partners in health and Zanmi Lasante experience. World Journal of Surgery. World J Surg. 2011;35(4):745-50. [PubMed]

16. Rajpura A, Boutros I, Khan T, Khan SA. Pakistan earthquake: experiences of a multidisciplinary surgical team. Prehosp Disaster Med. 2010;25(4):361-7. [PubMed]

17. Shin TC, Teng TL. An overview of the 1999 Chi-Chi, Taiwan, earthquake. Bulletin of the seismological society of America. 2001 Oct 1;91(5):895-913. [Full Text | DOI]

18. Rafferty JP, Pletcher K. Sichuan earthquake of 2008. [ Full Text]

19. Clover AJ, Rannan-Eliya S, Saeed W, Buxton R, Majumder S, Hettiaratchy SP et al. Experience of an orthoplastic limb salvage team after the Haiti earthquake: analysis of caseload and early outcomes. Plast Reconstr Surg. 2011;127(6):2373-80. [PubMed]
20. Zhang J, Ding W, Chen A, Jiang H. The prominent role of plastic surgery in the Wenchuan earthquake disaster. J Trauma. 2010;69(4):964-9. [PubMed]

21. Wolf $\mathrm{Y}$, Bar-Dayan Y, Mankuta D, Finestone A, Onn E, Morgenstern $\mathrm{D}$ et al. An earthquake disaster in Turkey: assessment of the need for plastic surgery services in a crisis intervention field hospital. Plast Reconstr Surg. 2001;107(1):163-8. [uuㄹed]

22. Phalkey R, Reinhardt JD, Marx M. Injury epidemiology after the 2001 Gujarat earthquake in India: a retrospective analysis of injuries treated at a rural hospital in the Kutch district immediately after the disaster. Glob Health Action. 2011;4:7196. [PubMed]

23. Yang C, Wang HY, Zhong HJ, Zhou L, Jiang DM, Du DY et al. The epidemiological analyses of trauma patients in Chongqing teaching hospitals following the Wenchuan earthquake. Injury. 2009;40(5):488-92. [ubMed]

24. Centers for disease control and prevention (CDC). Post earthquake injuries treated at a field hospital-Haiti 2010. MMWR. 2011;59(51):1673-7. [PubMed]

25. Xu Y, Huang J, Zhon J, Zeng Y. Patterns of abdominal injury in 37,387 disaster patients from the Wenchuan earthquake. Emerg Med J. 2013;30(7):538-42. [PubMed]

26. Guha-Sapir D, Vos F. Earthquakes: an epidemiological perspective on patterns and trends. In: Spence R, So E, Scawthorn C (Eds). Human casualties in earthquakes: progress in modeling and mitigation. New York: Springer. 2011(2) pp.13-24. [Full Text]

27. Lechat MF. Disasters and public health. Bull World Health Organ. 1979;57(1):11-7. [PubMed]

28. Bulut M, Fedakar R, Akkose S, Akgoz S, Ozguc H, Tokyay R. Medical experience of a university hospital in Turkey after the 1999 Marmara earthquake. Emergency medicine journal. 2005 Jul;22(7):494-8. [ㅁubMed]

The Author(s) 2018.

This work is licensed under a Creative Commons Attribution 4.0 International License. The images or other third party material in this article are included in the article's Creative Commons license, unless indicated otherwise in the credit line; if the material is not included under the Creative Commons license, users will need to obtain permission from the license holder to reproduce the material. To view a copy of this license, visit http://creativecommons.org/licenses/by/4.0/ 